\title{
ОСОБЛИВОСТІ ДЕРЖАВНОЇ АТЕСТАЦІЇ СТУДЕНТІВ ГАЛУЗІ ЗНАНЬ "ФАРМАЦІЯ"
}

\author{
В. П. Черних, І. С. Гриценко, С. В. Огарь, Л. М. Віннік \\ Національний фармащевтичний університет
}

\section{PECULIARITIES OF THE STATE ATTESTATION OF STUDENTS IN THE FIELD OF KNOWLEDGE "PHARMACY".}

\author{
V. P. Chernykh, I. S. Hrytsenko, S. V. Ohar, L. M. Vinnik \\ National University of Pharmacy
}

\begin{abstract}
У статті висвітлено особливості державної атестації студентів галузі знань “Фармація”.
The article adduces the peculiarities of the state attestation of students in the field of knowledge "Pharmacy".
\end{abstract}

Вступ. Відповідно до галузевих стандартів вищої фармацевтичної освіти освітньо-кваліфікаційного рівня "спеціаліст" та наказів МОЗ України від 08.07.2010 p. № 542, № 543, № 544 державна атестація випускників спеціальностей “Фармація”, “Клінічна фармація”, “Технологія парфумерно-косметичних засобів" включає стандартизований тестовий іспит i державний комплексний практично-орієнтований іспит і (або) захист дипломної роботи.

Основна частина. Стандартизований тестовий іспит проводиться відповідно до Положення про систему ліцензійних інтегрованих іспитів, затвердженого наказом МОЗ України від 14.08.1998 року № 251 і складається 3 двох частин: “Крок 1" і “Крок 2”. "Крок 1. Фармація" є семестровим інтегрованим іспитом, який проводиться після вивчення дисциплін природничо-наукового циклу і визначає показники якості фахової компоненти базової вищої освіти. "Крок 2. Фармація”, “Крок 2. Клінічна фармація”, “Крок 2. Технологія парфумерно-косметичних засобів" $є$ складовою державної атестації випускників відповідних спеціальностей і визначає показники якості фахової компоненти повної вищої освіти.

Державний комплексний практично-оріснтований іспит проводиться державною екзаменаційною комісією, яка оцінює відповідно до вимог освітньо-кваліфікаційної характеристики професійні уміння та навички, а також здатність вирішення ситуаційних завдань.

Студенти випускного курсу спеціальності “Фармація” складають комплексні практично-орієнтовані державні іспити з таких дисциплін, як: фармацевтична хімія, фармакогнозія, клінічна фармація, технологія лікарських засобів, управління та економіка у фармації.

Студенти випускного курсу спеціальності “Клінічна фармація" складають комплексні практично-орієнтовані державні іспити з таких дисциплін, як: медична хімія, фармакогнозія, фармацевтична опіка 3 клінічною фармакологією, технологія лікарських засобів, організація та управління у фармації.

Студенти випускного курсу спеціальності “Технологія парфумерно-косметичних засобів” складають комплексні практично-орієнтовані державні іспити 3 таких дисциплін, як: косметологія, управління та економіка у фармації та парфумерно-косметичній галузі, фармацевтична та косметична хімія, технологія косметичних та парфумерних засобів.

Практично-орієнтований державний іспит спрямований на перевірку готовності випускника здійснювати професійні уміння та навички діяльності на первинній посаді, які неможливо оцінити методом стандартизованого тестування.

Складання практично-орієнтованого державного іспиту проводиться на відкритому засіданні державної екзаменаційної комісії за участю не менше половини їі складу.

Білет до комплексного практично-орієнтованого іспиту має містити одне комплексне ситуаційне завдання $з$ дисципліни (при необхідності розрахунковопрактичну задачу), що входить до комплексу.

Професійні вміння та навички студентів випускного курсу спеціальності “Фармація” оцінюються:

• $з$ дисципліни “Фармацевтична хімія” :

(ㄱ В. П. Черних, І. С. Гриценко, С. В. Огарь, Л. М. Віннік 
- володіння фармакопейними методами якісного та кількісного аналізу лікарських засобів;

• 3 дисципліни “Фармакогнозія” :

- визначення лікарської рослинної сировини за морфологічними та анатомічними ознаками;

- визначення групи біологічно активних речовин, засобів чи продуктів рослинного походження та їх фармакологічна дія;

• $з$ дисципліни “Клінічна фармація":

- фармацевтична опіка при відпуску лікарських засобів за рецептами та без рецептів лікарів;

- 3 дисципліни “Технологія лікарських засобів" :

- приготування та оформлення до відпуску екстемпоральних лікарських форм згідно з вимогами нормативних документів з урахуванням фізико-хімічних властивостей лікарських та допоміжних речовин;

- контроль при відпуску виготовленої лікарської форми;

- обгрунтування технологічного процесу виготовлення готових лікарських засобів;

- оцінка якості готових лікарських засобів;

• з дисципліни “Управління та економіка у фармації”:

- організація лікарського забезпечення населення та лікувально-профілактичних закладів;

- аналіз показників торгово-фінансової діяльності аптек, облік та звітність;

- управління фармацевтичним підприємством;

- дослідження фармацевтичного ринку та розроблення комплексу маркетингу.

Професійні вміння та навички студентів випускного курсу спеціальності “Клінічна фармація” оцінюються:

- 3 дисципліни "Медична хімія" :

- володіння фізико-хімічними та інструментальними методами ідентифікації лікарських сполук та їх метаболітів;

- знання хімічних несумісностей ліків при їх комплексному застосуванні;

• 3 дисципліни “Фармакогнозія” :

- визначення лікарської рослинної сировини за морфологічними та анатомічними ознаками;

- визначення групи біологічно активних речовин, засобів чи продуктів рослинного походження та їх фармакологічна дія;

- раціональне використання та взаємозаміна інших препаратів;

• $з$ дисципліни “Фармацевтична опіка з клінічною фармакологією”:

- фармацевтична опіка при відпуску лікарських засобів за рецептами та без рецептів лікарів;

• 3 дисципліни “Технологія лікарських засобів”:
- приготування та оформлення до відпуску лікарських форм згідно з вимогами нормативних документів з урахуванням фізико-хімічних властивостей лікарських та допоміжних речовин;

- контроль при відпуску виготовленої лікарської форми;

- складання технологічних і апаратурних схем виробництва готових лікарських засобів;

- обгрунтування технологічного процесу виготовлення готових лікарських засобів;

- оцінка якості готових лікарських засобів;

• здисципліни “Організація тауправління у фармації”:

- організація інформаційно-консультаційноїдопомоги щодо раціонального застосування ліків;

- облік, звітність та економічні розрахунки діяльності аптек;

- управління фармацевтичним підприємством;

- дослідження фармацевтичного ринку та розроблення комплексу маркетингу.

Професійні вміння та навички студентів випускного курсу спеціальності "Технологія парфумернокосметичних засобів" оцінюються:

• $з$ дисципліни “Косметологія":

- вибір раціональних косметичних засобів залежно від стану шкіри та її придатків, схеми корекції косметичного недоліку;

- оцінка результатів ефективності запропонованої схеми догляду за шкірою;

• з дисципліни "Управління та економіка у фармації та парфумерно-косметичній галузі” :

- організація забезпечення населення лікарськими та парфумерно-косметичними засобами;

- аналіз показників торгово-фінансової діяльності аптек та парфумерно-косметичних закладів, облік i звітність;

- управління фармацевтичним підприємством та парфумерно-косметичним закладом;

- дослідження парфумерно-косметичного ринку та розроблення комплексу маркетингу;

- 3 дисципліни “Фармацевтична та косметична хімія":

- володіння фармакопейними методами ідентифікації та кількісного визначення лікарських засобів;

- стандартизація парфумерно-косметичних засобів;

• $з$ дисципліни "Технологія косметичних та парфумерних засобів":

- обгрунтування технологічного процесу виготовлення косметичних та парфумерних засобів;

- оцінка якості готових косметичних та парфумерних засобів.

Під час державного іспиту випускник отримує оцін- 
ку за кожну дисципліну практично-орієнтованого іспиту, що виноситься на державну атестацію.

Оцінка умінь та навичок, що перевіряються на практично-орієнтованому державному іспиті з відповідних спеціальностей, а також вирішення ситуаційних завдань (розрахунково-практичних задач) проводиться згідно з галузевими стандартами відповідних спеціальностей та критеріями, визначеними кожною випусковою кафедрою у методичних рекомендаціях з підготовки до державного іспиту з дисципліни.

Дипломна робота може виконуватись як комплексна дипломна робота або монотематична. Захист дипломної роботи проводиться замість складання державного екзамену (екзаменів) з дисципліни (дисциплін). Дипломна робота виконується студентом за темами, визначеними випусковими кафедрами та затвердженими в установленому порядку. Захист дипломних робіт проводиться на відкритому засіданні ДЕК при обов' язковій присутності голови державної екзаменаційної комісії.

Висновок. Організація та проведення комплексного практично-орієнтованого державного іспиту передбачають компетенції, що мають виконувати студенти на первинній посаді провізора відповідно до кваліфікаційної характеристики.

\section{Література}

1. Про затвердження Положення про систему ліцензійних інтегрованих іспитів фахівців з вищою освітою напрямів "Медицина" i “Фармація" : наказ МО3 України від 14.08 .98 р. №251.

2. Про внесення змін до Навчального плану підготовки фахівців освітньо-кваліфікаційного рівня “спеціаліст” кваліфікації “провізор” у вищих навчальних закладах IV рівня акредитації за спеціальністю “Фармація”, затвердженого наказом МОЗ від 07.12.2009 р. № 930 : наказ МОЗ України від 08.07.2010 р. № 542 .

3. Про внесення змін до Навчального плану підготовки фахівців освітньо-кваліфікаційного рівня “спеціаліст” кваліфікації “клінічний провізор” у вищих навчальних закладах IV рівня акредитації за спеціальністю “Клінічна фарма-

ція”, затвердженого наказом МОЗ від 07.12.2009 р. № 931 : наказ МОЗ України від 08.07.2010 p. № 543.

4. Про внесення змін до Навчального плану підготовки фахівців освітньо-кваліфікаційного рівня “спеціаліст” кваліфікації “провізор-косметолог” у вищих навчальних закладах IV рівня акредитації за спеціальністю “Технологія парфумерно-косметичних засобів”, затвердженого наказом МО3 від 07.12.2009 р. № 932 : наказ МОЗ України від 08.07.2010 p. №544.

5. Про затвердження складових галузевих стандартів вищої освіти зі спеціальності 7.110201 “Фармація”, 7.110202 “Технологія парфумерно-косметичних засобів”, 7.110206 "Клінічна фармація" : наказ МОН України від 29.07.2004 p. №629. 